\footnotetext{
${ }^{1}$ United Graduate school of Veterinary Sciences, Yamaguchi University, Laboratory of Animal Reproduction and Applied Biotechnology, Yoshida, Yamaguchi, Japan

${ }^{2}$ Faculty of Science, Technology and Environmental Studies, Open University of Tanzania, Dar es Salaam, Tanzania
}

NAMDORI R. MTANGO ${ }^{1}$, MODEST D. VARISANGA ${ }^{2}$, DONG Y. JUAN ${ }^{1}$, PIMPRAPAR WONGRISEKEAO ${ }^{1}$ and TATSUYUKI SUZUKI ${ }^{1}$

\title{
Development to Blastocyst Stage of Pig Oocytes Matured, Fertilized and Electroactivated In Vitro
}

\begin{abstract}
Summary
This study was designed 1) to determine the effectiveness of two in vitro maturation (IVM) media (tissue culture medium [TCM] and modified synthetic oviduct fluid supplemented with amino acids [mSOFaa]), 2) to compare the effects of two in vitro fertilization (IVF) media (modified Tris-buffered medium [mTBM] and mSOFaa) on the developmental competence of pig oocytes, and 3) to test the activation ability of IVM pig oocytes matured in TCM or mSOFaa, electroactivated and cultured in mSOFaa. The nuclear maturation rates were similar between IVM media (91.0 \% vs. $89.0 \%$ ). A similar result was obtained when the activation rates were $54.2 \%$ in TCM and $56.0 \%$ in mSOFaa, and the blastocyst rates were $7.9 \%$ and $6.1 \%$, respectively. There was no significant difference between mSOFaa and mTBM in the percentage of embryos with two pronuclei $33.2 \%$ vs. $13.8 \%$ or polypronuclei $5.3 \%$ vs. $13.4 \%$. The cleavage rate was the same in both media. The medium mSOFaa gave a significantly higher $(\mathrm{P}<0.05)$ blastocyst rate than mTBM $(12.7 \%$ vs. $3.9 \%)$. We concluded that mSOFaa can enhance in vitro maturation, fertilization and culture of pig oocytes.
\end{abstract}

Key Words: pig, IVM, IVF, electroactivation, mSOFaa

\section{Zusammenfassung}

Titel der Arbeit: Einfluss unterschiedlicher Medien bzw. Elektroaktivierung auf die In-vitro-Reifung, -Befruchtung und -Kultivierung von Schweineoozyten

Mit der vorliegenden Arbeit wurden drei Ziele verfolgt. Das erste bestand in der Prüfung des Einflusses von zwei verschiedenen Medien (TCM, mSOFaa) auf die Reifung porciner Oozyten in vitro. Als Kriterium der erfolgreichen Reifung diente das Erreichen der Metaphase II der Meiose. Zwischen beiden Gruppen bestand hinsichtlich der Reifungsrate (91,0 \% bzw. 89,0 \%) kein statistisch gesicherter Unterschied. In einem zweiten Ansatz wurden Oozyten, die in den o.g. Reifungsmedien über die Dauer von 48 h gereift wurden, mit Elektropulsen aktiviert. Der Anteil aktivierter Oozyten (54,2 \% bzw. 56,0 \%), die Teilungsrate (56,2 \% bzw. 57,9 \%) und der Anteil Blastozysten (7,9 \% bzw. 6,1 \%) unterschieden sich statistisch nicht zwischen den Gruppen. Drittens wurde der Einfluss von zwei unterschiedlichen Befruchtungsmedien (mSOFaa, mTBM) auf die In-vitro-Entwicklungskompetenz von Schweineoozyten untersucht. Die Anteile Oozyten mit zwei (33,2 \% bzw. 13,8 \%) und mehr Vorkernen (5,3 \% bzw. 13,4 \%) unterschieden sich nicht signifikant zwischen den Gruppen. Mit dem Befruchtungsmedium mSOFaa wurde jedoch eine vergleichsweise signifikant höhere Blastozystenrate erreicht (24,9 \% bzw. 8,8 \%). Es wird geschlussfolgert, dass die In-vitro-Reifung, -Befruchtung und -Kultivierung porciner Oozyten und Embryonen mit dem Medium mSOFaa verbessert werden kann.

Schlüsselwörter: Schwein, IVM, IVF, Elektroaktivierung, mSOFaa

\section{Introduction}

Livestock biotechnology uses an arsenal of in vitro reproductive procedures, such as gene transfer, cryopreservation of oocytes and embryos, in vitro production of embryos, embryo sexing, and nuclear transfer. There is tremendous interest in producing large quantities of matured pig oocytes and embryos through in vitro maturation, fertilization and culture (IVM/IVF/IVC) techniques. Because of their physiological similarities to human, pigs have become increasingly important as 
potential xenograft donors and as transgenic animals that produce specific proteins. Despite considerable research into methods for the in vitro production of embryos in pig, only a very small proportion of pig oocytes develop to offspring compared with those of cattle (WILMUT et al., 2000; NIEMANN and RATH, 2001). The successful large-scale production of pig embryos through in vitro techniques faces many difficulties. These difficulties include inefficient oocyte maturation and fertilization techniques, poor developmental capacity of in vitro-produced embryos, and suboptimal embryo culture conditions (ABEYDEERA, 2002). The difficulties could result from the fact that prepubertal gilt oocytes are commonly used (FUNAHASHI and DAY, 1996). In pigs, although some piglets have been obtained after transfer of embryos produced from oocytes matured and fertilized in vitro, success in producing normal pig embryos in vitro is still limited to a few laboratories. Researchers visualize that the development of new in vitro techniques or optimization of existing techniques will result in further advances in embryo biotechnology.

The significant progress achieved in animal cloning by using nuclear transfer has aroused great interest in the artificial activation of eggs of large domestic animals. Parthenogenesis is a useful means of analyzing epigenetic changes i.e. genomic imprinting of maternal genes, leadings to expression or repression of certain genes of either maternal or paternal origin during embryonic development (KONO et al., 1996). Under natural conditions, the sperm that penetrates the egg induces oocyte activation and initiates meiosis. Artificial stimuli that elevate the cytoplasmic levels of calcium ions can induce activation of oocytes even without penetration by sperm (For review see KAUFMAN, 1983). A wide spectrum of activating stimuli, e.g.including ionophore, ethanol, electrical pulses, and other chemicals, is used to induce artificial activation of mammalian eggs (PRATHER et al., 1997; GRUPEN et al., 1999; AZUMA et al., 2001; JILEK et al., 2001;). However, the search for other suitable methods continues

The present study was designed 1) to determine the effectiveness of two oocyte maturation media, 2) to compare the effect of two fertilization media on the developmental competence of pig oocytes, and 3) to test the activation ability of pig oocytes matured in the two maturation media, electroactivated, and cultured in mSOFaa.

\section{Materials and methods \\ Collection of oocytes and IVM}

Ovaries were collected from prepubertal gilts at a local slaughterhouse and transported to the laboratory in $0.9 \%(\mathrm{w} / \mathrm{v}) \mathrm{NaCl}$ containing $100 \mathrm{IU} / \mathrm{mL}$ Penicillin G potassium, and $0.1 \mathrm{mg} / \mathrm{mL}$ streptomycin sulfate at $35^{\circ} \mathrm{C}$. Within $2 \mathrm{~h}$ after slaughter, the follicular contents were recovered by aspiration of small antral follicles (2-6mm in diameter) with an 18-gauge needle attached to a 10-mL syringe, using modified Dulbecco's phosphate buffered saline (Gibco, Grand Island, NY, USA) $+3 \mathrm{mg} / \mathrm{ml}$ bovine serum albumin (BSA, Fatty-acid-free; Sigma Chemical Co., St. Louis, MO, USA) as an aspiration medium. Only COCs with uniform ooplasm and a compact cumulus cell mass were selected. Groups of 50 selected COCs were cultured in $500 \mu \mathrm{L}$ of maturation medium (see Experimental Design, below) for 22-24 h. After maturation, the oocytes were washed and transferred without hormonal supplementation for an 
additional 20-22 h of culture. All cultures were covered with mineral oil and cultured at $38.5{ }^{\circ} \mathrm{C}$ under air with $5 \% \mathrm{CO}_{2}$.

\section{Activation of oocytes}

After 48 hours of maturation culture, the oocytes were denuded of associated somatic cells by repeated pipetting through a narrow glass pipette. Those oocytes that had extruded their first polar body were identified, isolated and maintained at $38.5{ }^{\circ} \mathrm{C}$ in modified synthetic oviduct fluid (mSOF) supplemented with $0.25 \mathrm{mM}$ HEPES and 10 $\%$ fetal calf serum (FCS; JRH Bioscience, Lenaxa, KS, USA) pending further treatment. The basic activation medium was $300 \mathrm{mM}$ mannitol supplemented with $0.05 \mathrm{mM} \mathrm{CaCl}_{2}, 0.1 \mathrm{mM} \mathrm{MgSO}_{4}$, and $0.01 \%$ BSA. After three washes in a pulsing medium, the oocytes were transferred to a fusion chamber with parallel electrodes set $1 \mathrm{~mm}$ apart containing the same activation medium and stimulated by a single DC pulse treatment of $1.65 \mathrm{KV} / \mathrm{cm}$ for $100 \mu \mathrm{s}$. After the pulse treatment, the eggs were washed in mSOF supplemented with $0.25 \mathrm{mM}$ HEPES and cultured in $\mathrm{mSOFa}$ supplemented with amino acids (mSOFaa) $+10 \%$ FCS at $38.5{ }^{\circ} \mathrm{C}$ in $5 \% \mathrm{CO}_{2}$ in air. The presence of pronuclei was assessed after $12 \mathrm{~h}$ of culture.

\section{Sperm preparation and IVF}

Thawed boar semen was used for IVF. Spermatozoa were thawed at $39^{\circ} \mathrm{C}$ for $1 \mathrm{~min}$ in a water bath and then diluted in $10 \mathrm{~mL}$ of $0.9 \% \mathrm{NaCl}$ containing $10 \mathrm{mg} / \mathrm{mL}$ BSA. The sperm suspension was centrifuged twice at $350 \mathrm{~g}$ for $3 \mathrm{~min}$, and the final sperm pellet was resuspended and preincubated in fertilization medium supplemented with 2 $\mathrm{mg} / \mathrm{mL}$ BSA at $38.5{ }^{\circ} \mathrm{C}$ for $1 \mathrm{~h}$. After IVM, COCs were washed three times in fertilization medium supplemented with $2 \mathrm{mM}$ caffeine (Sigma, Chemical Co., St. Louis, MO, USA ). Fifteen COCs in $20 \mu \mathrm{L}$ of fertilization medium were introduced into a $60-\mu \mathrm{L}$ fertilization drop covered by mineral oil, and $20 \mu \mathrm{L}$ of sperm suspension was added to each fertilization drop to a final concentration of $1 \times 10^{6} \mathrm{sperm} / \mathrm{mL}$. Spermatozoa and oocytes were co-incubated for $6 \mathrm{~h}$ at $38.5{ }^{\circ} \mathrm{C}$ in $5 \% \mathrm{CO}_{2}$ in humidified air.

\section{Embryo culture}

The culture medium for all experiments was mSOFaa. At $6 \mathrm{~h}$ after IVF, oocytes were freed from cumulus cells and spermatozoa by repeated pipetting. Presumptive zygotes were washed three times in culture medium and placed in $20-\mu \mathrm{L}$ microdrops (20 zygote/drop) of mSOFaa under mineral oil at $38.5^{\circ} \mathrm{C}$ in $5 \% \mathrm{CO}_{2}$ in humidified air. At $72 \mathrm{~h}$ after insemination, embryos were washed and transferred to fresh drops of culture medium supplemented with $5.5 \mathrm{mM}$ glucose. Embryos were cultured for an additional 7 days after IVF.

\section{Evaluation of nuclear status of oocytes}

At the end of the culture, the oocytes were mounted on a slide, air-dried and fixed with absolute ethanol for at least $24 \mathrm{~h}$. They were then stained with $10 \mu \mathrm{g} / \mathrm{mL}$ Hoechst 33342 in $2.3 \%$ sodium citrate and $25 \%$ (v/v) glycerol. The oocytes were examined under a fluorescence microscope (Nikon Optiphot, Tokyo, Japan). Oocytes that reached metaphase II (MII) were recorded as matured. Activation was considered to 
have occurred if the oocytes were in the pronuclear stage. The presence of polypronuclei revealed polyspermy.

\section{Experimental design}

\section{Experiment 1}

This experiment was carried out to test two types of maturation media: HEPESbuffered (TCM: Earle salts; Gibco, Grand Island, NY, USA) and mSOFaa. The TCM was supplemented with $0.6 \mathrm{mM}$ cysteine $0.1 \mathrm{mg} / \mathrm{mL}$ sodium pyruvate, $0.01 \%(\mathrm{w} / \mathrm{v})$ polyvinyl pyrrolidone ( $\mathrm{Mr}$ 10, 000. all Sigma, Chemical Co., St. Louis, MO, USA). The mSOFaa consisted of $107.70 \mathrm{mM} \mathrm{Nacl}, 7.16 \mathrm{mM} \mathrm{KCl}, 1.19 \mathrm{mM} \mathrm{KH} \mathrm{PO}_{4}, 1.71$ $\mathrm{mM} \mathrm{CaCl} 2,0.49 \mathrm{mM} \mathrm{MgCl}_{2}, 6 \mathrm{H}_{2} \mathrm{O}, 25.07 \mathrm{mM}$ NaHCO3, 1mM Glutamine, $0.30 \mathrm{mM}$ sodium pyruvate, $3.30 \mathrm{mM}$ sodium lactate, $7 \mathrm{mM}$ taurine, $5 \mathrm{mM}$ hypotaurine, $4 \mathrm{mg} / \mathrm{mL}$ BSA and MEM and BME amino acids (Sigma, Chemical Co., St. Louis, MO, USA) at 10.0 and $20.0 \mathrm{ml} / \mathrm{L}$. Both media were supplemented with $10 \mathrm{ng} / \mathrm{mL}$ epidermal growth factor (EGF; Sigma, Chemical Co., St. Louis, MO, USA), $100 \mathrm{IU} / \mathrm{mL}$ penicillin G potassium, $0.1 \mathrm{mg} / \mathrm{mL}$ streptomycin sulfate, $10 \%$ (v/v) heat-treated (FCS), $10 \mathrm{IU} / \mathrm{mL}$ PMSG (Denka Pharmaceutical Co., Kawasaki, Japan), and 10 IU/mL human chorionic gonadotropin (Denka Pharmaceutical Co., Kawasaki, Japan). The percentage of oocytes that reached at MII was checked after maturation culture.

\section{Experiment 2}

The objective of this experiment was to test the activation ability of pig oocytes matured in vitro for $48 \mathrm{~h}$ either in TCM or mSOFaa, electroactivated as described above, and further cultured in mSOFaa. Some oocytes were stained at $12 \mathrm{~h}$ of culture to check activation potential. The rest were cultured for 7 more days to reveal their developmental capacity.

\section{Experiment 3}

The aim of this experiment was to compare the effect of two fertilization media: modified Tris-buffered medium (mTBM) and mSOFaa. Oocytes were cultured in vitro for $44 \mathrm{~h}$ in TCM and fertilized in either mTBM or mSOFaa. The presumptive zygotes were then cultured in mSOFaa. Some presumptive zygotes were fixed at $12 \mathrm{~h}$ of culture to check the formation of male and female pronuclei (dipronucleus) and polypronucleus. The other were cultured for 7 days to reveal their development. On day 7 of culture (IVF = day 0), the blastocysts were stained to check the cell number.

\section{Statistical analysis}

Culture media were compared by calculating maturation, activation, dipronucleus, polypronucleus, cleavage, and blastocyst rates for each replicate. The percentage data were assessed by ANOVA. Means were compared by a least significant difference test. All percentage data were converted by using arcsine transformation before ANOVA. A probability level of $\mathrm{P}<0.05$ was considered statistically significant.

\section{Results}

\section{Experiment 1}

Oocyte maturation data were collected from the two maturation media in 6 replicates (Table 1). There was no significant difference between TCM and mSOFaa in meiotic 
maturation of oocytes, as evidenced by MII chromatin or 2 polar bodies and at least 2 pronuclei.

Table 1

Maturation rates of in vitro-matured pig oocytes in TCM and mSOFaa

\begin{tabular}{ccc}
\hline Treatment & $\begin{array}{c}\text { No. of oocytes examined } \\
(\mathrm{n})\end{array}$ & $\begin{array}{c}\text { Oocytes at MII } \\
(\mathrm{n})(\%)\end{array}$ \\
\hline TCM & 100 & $91(91.0)$ \\
mSOFaa & 100 & $89(89.0)$ \\
\hline
\end{tabular}

\section{Experiment 2}

In this experiment, activation of oocytes cultured in vitro for $48 \mathrm{~h}$ in TCM or mSOFaa was observed in 4 replicates (Table 2). A total of 796 oocytes were used either for checking the status of oocyte after activation treatments $(n=30)$ or for development to blastocysts $(n=736)$. Portion of activated oocytes, cleavage rates and blastocyst rates were no significantly different between media. Figure 1 shows the blastocysts obtained after electroactivation of matured pig oocytes.

Table 2

Activation and developmental rates of in vitro-electroactivated pig embryos matured in TCM and mSOFaa

\begin{tabular}{cccccc}
\hline $\begin{array}{c}\text { Oocytes } \\
\text { matured in }\end{array}$ & $\begin{array}{c}\text { No. of oocytes } \\
\text { stained }\end{array}$ & $\begin{array}{c}\text { Portion of } \\
\text { Oocytes } \\
\text { activated }\end{array}$ & $\begin{array}{c}\text { No. of oocytes } \\
\text { used for } \\
\text { activation } \\
(\mathrm{n})\end{array}$ & $\begin{array}{c}\text { Cleaved } \\
\text { oocytes }\end{array}$ & Blastocysts \\
TCM & 120 & $(\%)$ & 379 & $56.2(213)$ & $7.9(30)$ \\
mSOFaa & 100 & 56.0 & 477 & $57.9(276)$ & $6.1(29)$ \\
\hline
\end{tabular}

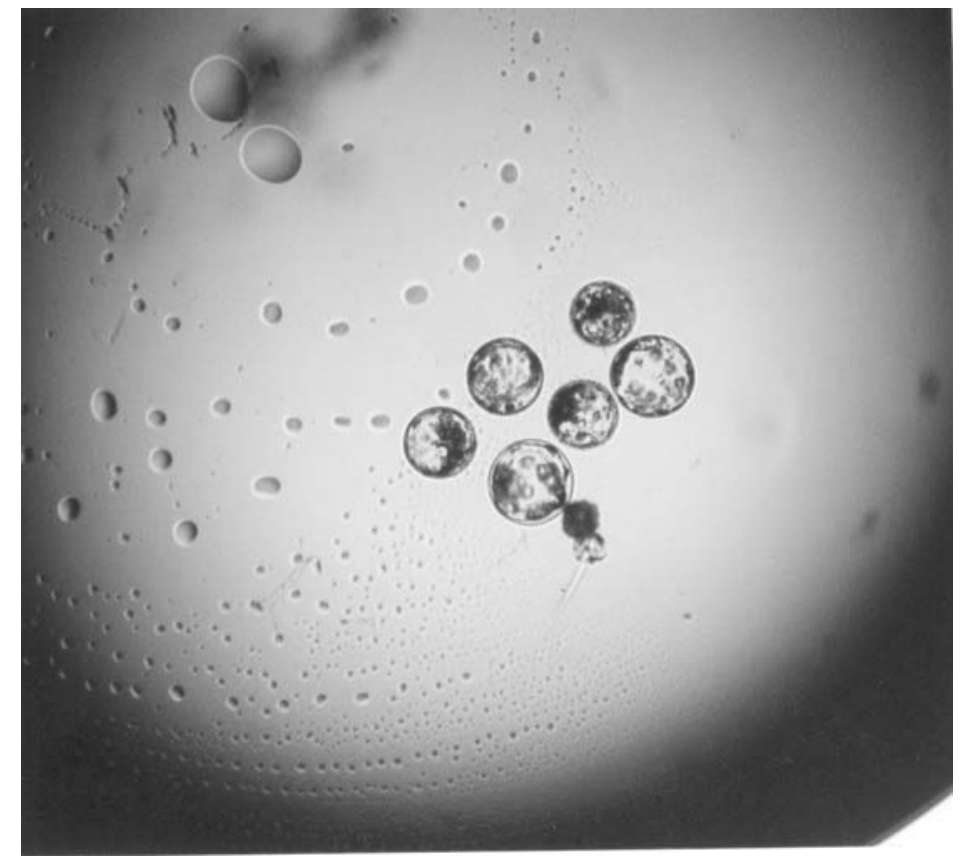

Fig 1: Blastocyst obtained after electroactivation of matured pig oocytes

\section{Experiment 3}

Table 3 summarizes the development rates of in vitro-produced pig embryos fertilized in two media. Frequency of single or multiple sperm penetration was not significantly 
different between media. At $48 \mathrm{~h}$ after insemination, $51.1 \%$ of oocytes fertilized in mSOFaa and $44.8 \%$ in mTBM had cleft evenly to at least the two-cell stage. A significantly higher portion of oocytes reached the blastocyst stage after fertilization in mSOFaa than in mTBM $(12.7 \%$ vs. $3.9 \%$; P < 0.05). Fertilization medium had no significant effect on cell numbers of blastocysts at seven days after insemination. However, mTBM tended to produce blastocysts with lower cell numbers than did mSOFaa. Figure 2 shows blastocysts obtained after IVM/IVF/IVC.

Table 3

Development rates of in vitro-produced pig embryos cultured in mSOFaa in dependence of fertilization media

\begin{tabular}{lccc}
\hline Parameter & & \multicolumn{2}{c}{ Fertilization medium } \\
& & mSOFaa & mTBM \\
\hline No. fixed zygotes & $(\mathrm{n})$ & 30 & 30 \\
Embryos with dipronucleus & $(\%)$ & 33.2 & 13.8 \\
Embryos with polypronucleus & $(\%)$ & 5.3 & 13.4 \\
Oocytes cultured & $(\mathrm{n})$ & 354 & 382 \\
Cleavage & $(\%)$ & 51.1 & 44.8 \\
& $(\mathrm{n})$ & 171 & 171 \\
Blastocysts on day 7 & $(\%)$ & $12.7^{\mathrm{a}}$ & $3.9^{\mathrm{b}}$ \\
& $(\mathrm{n})$ & 45 & 15 \\
Blastocysts from cleaved oocytes & $(\%)$ & $24.9^{\mathrm{a}}$ & $8.8^{\mathrm{b}}$ \\
Cell number of blastocysts on day 7 & Mean \pm SEM & $64.4 \pm 4.8$ & $52.1 \pm 3.1$ \\
\hline
\end{tabular}

Values within a raw with different superscripts are statistically different, $\mathrm{P}<0.05$.

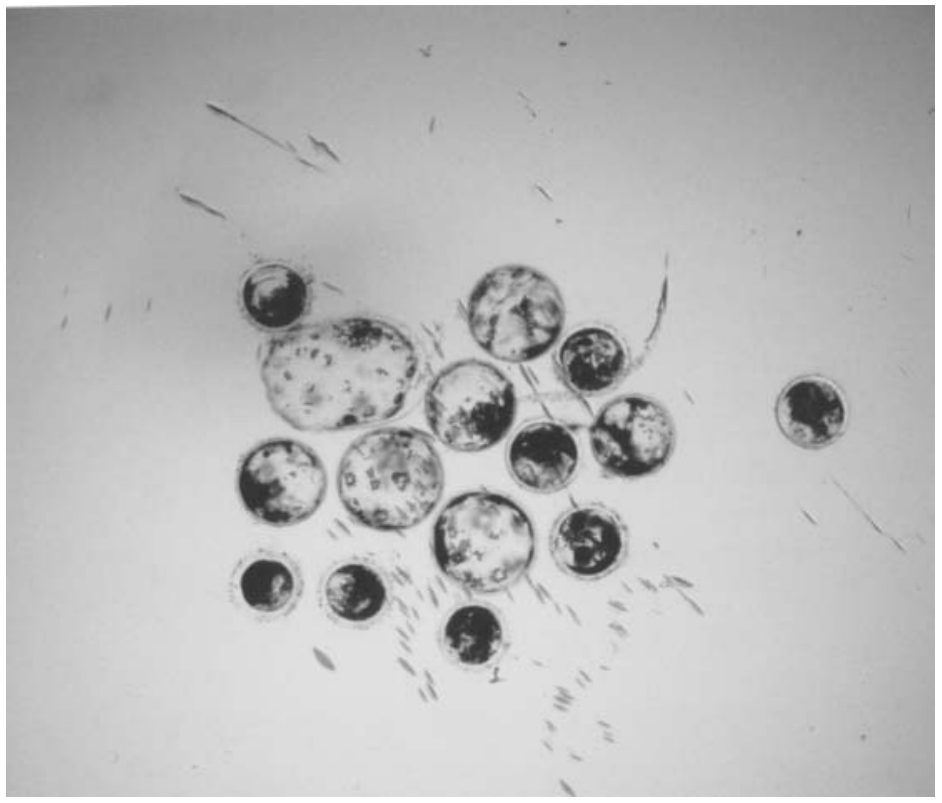

Fig 2: Blastocyst obtained after IVM/IVF/IVF of pig oocytes

\section{Discussion}

Successful maturation of pig oocytes in vitro can be achieved in various culture medium types (simple or complex) containing FCS or follicular fluid and other supplements. The rate of oocytes at the MII stage after the in vitro maturation period that we found is very close to those reported in previous studies (YOSHIDA et al., 1992; ABEYDEERA et al., 2001; KIKUCHI et al., 2002). EGF has been shown to be 
a potent stimulator of both, resumption and completion of nuclear maturation of pig oocytes (GRUPEN et al., 1997; ILLERA et al., 1998; SIROTKIN et al., 2000).

In vitro penetration of IVM oocytes has been realized by using various types of fertilization media in conjunction with fresh or frozen-thawed sperm. We used frozenthawed-sperm. Single and multiple sperm penetrations in this experiment occurred at the same rates between treatments. This may be due to the limited exposure to gonadotropins, and to supplementation of EGF and cysteine in our media. Increased male pronucleus formation caused by cysteine supplementation is correlated with a higher intracellular glutathione content (DAY et al., 2000; ABEYDEERA, 2001). The synthesis of glutathione during oocyte maturation is a prerequisite for nuclear chromatin decondensation in hamster and pig sperm cells and for successful male pronucleus formation (PERREAULT et al., 1988; YOSHIDA et al., 1993). The ability of the cytoplasm to transform a penetrated sperm nucleus into a male pronucleus is efficient in oocytes matured and fertilized in the presence of cumulus cells. Intracellular glutathione content seems to depend on the presence of cumulus cells during culture (FUNAHASHI and DAY, 1995; YAMAUCHI and NAGAI, 1999).

Polyspermy is still a major problem in the in vitro production of pig embryos. In our work, mSOFaa produced in tendency a lower rate of polypronuclear oocytes than that of the traditional mTBM, although there was no significant difference. The ideal IVF system should result in a high penetration rate ( $>80 \%)$ with a low incidence of polyspermy (<10\%) (ABEYDEERA, 2002). In our case the oocytes fertilized with mSOFaa had $<10 \%$ embryos with polypronucleus. The low polyspermy rate may be due to the low number of sperm cells used and to full supplementation of essential and nonessential amino acids in the mSOFaa. Although polyspermy is a major problem in the in vitro production of pig embryos, there are some reports that polyspermic zygotes cleave and develop to the blastocyst stage at a similar rate as dipronuclear oocytes, and even result in pregnancies and the birth of piglets with normal ploidy (HAN et al., 1999a,b). It seems that some polypronuclear pig oocytes possess a mechanism to correct their ploidy.

The fertilization media used did not affect the cleavage rate but did affect the portion of oocytes that developed to the blastocyst stage and their cell numbers. As above, full supplementation of amino acids, taurine, and hypotaurine in the fertilization media seemed to have a positive effect.

The culture medium composition has a significant influence on the developmental competence of IVM -IVF embryos. Many studies have been done to identify the necessary components of media for the development of oocytes to blastocysts. It was hypothesized that the presence of glucose and a higher lactate content in modified Waymouth medium may be responsible for the poor development of IVM -IVF derived embryos. Culture of pig embryos in modified NCSU 23 without glucose but supplemented with low levels of lactate $(4.5 \mathrm{mM})$ and pyruvate $(0.33 \mathrm{mM})$ for the first $72 \mathrm{~h}$ followed by culture in NCSU 23 with glucose for the next $72 \mathrm{~h}$ improved blastocyst development compared with those cultured for $144 \mathrm{~h}$ in NCSU 23 (reviewed by ABEYDEERA, 2002). In our experiment, the culture medium was supplemented with low lactate $(3.3 \mathrm{mM})$, and embryos were cultured without glucose for the first 72 h.

In our study, the oocytes were artificially activated with a single square pulse of direct current. The conditions under which stimulation is administered for activating oocytes 
are important for oocyte development (JOLLIFF and PRATHER, 1997; LIU et al., 1997). The use of repetitive electro-stimulation for the induction of parthenogenetic activation, which mimicked the pattern of intracellular Ca2+ oscillation in the normal process of fertilization, improved the proportion of eggs developing to blastocyst stage in vitro in rabbit (OZIL, 1990). However, when repetitive electro-stimulation was applied in our work, oocytes did not develop to blastocysts (UNPUBLISHED DATA). Diploid pig oocytes, that were matured in vitro and electroactivated by a single square pulse could develop up to day 29 after activation (KURE-BAYASHI et al., 2000). Culture conditions can affect the cleaving ability of in vitro-matured and activated porcine oocytes before the 4- cell stage. In our experiment there was no effect of culture conditions. Oocyte were able to surpass the 4-cell stage and reach the blastocyst stage after maturation in TCM or mSOFaa.

The mitotic stimuli in the early mammalian embryo have not been unequivocally identified. One hypothesis is that the embryo releases autocrine growth factors. Experiments were done to determine whether such putative growth factors were limited by dilution, and hence secreted, embryo development was observed in dependence on volume of medium per embryo (O’NEIL, 1997). From these experiments it was concluded that when embryos were cultured at a amount of one embryo per $\mu \mathrm{L}$ of medium, there is an enhancement in blastulation and cell number per embryo. Increasing the volume of culture medium to $10-100 \mu \mathrm{L}$ per embryo results in a loss of autocrine embryotrophic effect. In our study we incubated one embryo per $\mu \mathrm{L}$ culture medium. Therefore we assume, that autocrine secretion played a big role.

In conclusion, this study shows that mSOFaa can be used as a culture medium for IVM/IVF/IVC of pig embryos.

\section{References}

ABEYDEERA, L. R.:

In vitro fertilization and embryo development in the pig. J. Reprod. Fertil., 58suppl (2001),159-173

ABEYDEERA, L. R.; WANG, W. H.; PRATHER, R. S.; DAY, B. N.:

Effect of incubation temperature on in vitro maturation of porcine oocytes: nuclear maturation, Fertilisation and developmental competence. Zygote, 9 (2001), 331-7

ABEYDEERA, L. R.: In vitro production of embryos in swine. Theriogenology, 57 (2002), 257-273

AZUMA, T.; IKEDA, S.; KONDO, T.; IMAI, H.; YAMADA, M.:

Ethylenediamine-N,N,N',N'-tetraacetic acid induces parthenogenetic activation of porcine oocytes at the germinal vesicle stage, leading to formation of blastocysts. Biol. Reprod., 64 (2001), 647-53

DAY, B. N.; ABEYDEERA, L. R.; PRATHER, R. S.:

Recent progress in pig embryo production through in vitro maturation and fertilization techniques. In JOHNSON L. A. and GUTHRIE, H. D. (ed), Boar Semen Preservation IV. Kansas: Allen Press Inc., (2000), 81-92

FUNAHASHI, H.; DAY, B. N.:

Current status of in vitro production of porcine embryos. Advances in swine in biomedical research, Volume 2. New York, USA, Plenum Press. (1996), 491-502

FUNAHASHI, H.; DAY, B. N.:

Effects of cumulus cells on glutathione content of porcine oocytes during in vitro maturation. J. Anim. Sci., 73 (1995), 90 abstr

GRUPEN, C. G.; NAGASHIMA, H.; NOTTLE, M. B.:

Role of epidermal growth factor and insulin-like growth factor-I on porcine oocyte maturation and embryonic development in vitro. Reprod. Fertil. Dev., 9 (1997), 571-5

GRUPEN, C. G.; VERMA, P. J. DU, Z. T.; McILFATRICK, S. M.; ASHMAN, R. J.; NOTTLE, M. B.: Activation of in vivo- and in vitro-derived porcine oocytes by using multiple electric pulses. Reprod. Fertil. Develop., 11 (1999), 457-462 
HAN, Y. M.; ABEYDEERA, L. R.; KIM, J. H.; MOON, H. B.; CABOT, R. A.; DAY, B. N.; PRATHER, R. S: Growth Retardation of Inner Cell Mass Cells in Polyspermic Porcine Embryos Produced In Vitro. Biol. Reprod., 60 (1999), 1110-1113

HAN, Y. M.; WANG, W. H.; ABEYDEERA, L. R.; PETERSEN, A. L.; KIM, J. H.; MURPHY, C.; CABOT, R. A.; DAY, B. N.; PRATHER, R. S:

Pronuclear location before the first cell division determines ploidy of polyspermic pig embryos. Biol. Reprod., 61 (1999), 1340-1346

ILLERA, M. J.; LORENZO, P. L.; ILLERA, J. C.; PETTERS, R. M.:

Developmental competence of immature pig oocytes under the influence of EGF, IGF-I, follicular fluid and gonadotropins during IVM-IVF processes. Int. J. Dev. Biol. 42 (1998), 1169-72

JILEK, F.; HUTTELOVA, R.; PETR, J.; HOLUBOYA, M.; ROZINEK, J.:

Activation of pig oocytes using calcium ionophore: effect of the protein kinase inhibitor 6dimethylaminopurine. Reprod. Domest. Anim., 36 (2001), 139-45

JOLLIFF, W. J., PRATHER, R. S.:

Parthenogenetic development of in vitro-matured, in vivo-cultured porcine oocytes beyond blastocyst. Biol. Reprod., 56 (1997), 544-548

LIU, L.; MOOR, R. M.:

Factors affecting electrical activation of porcine oocytes matured in vitro. Anim. Reprod. Sci., 48 (1997), 67-80

KAUFMAN, M. H.:

Early Mammalian Development: Parthenogenetic studies. (1983) Cambridge University Press, Cambridge

KIKUCHI, K.; ONISHI, A.; KASHIWAZAKI, N.; IWAMOTO, M.; NOGUCHI, J.; KANEKO, H.; AKITA, T.; NAGAI, T.:

Successful Piglet Production after Transfer of Blastocysts Produced by a Modified In Vitro System. Biol Reprod, 66 (2002), 1033-1041

KONO, T.; OBATA, Y.; YOSHIMIZU, T.; NAKAHARA, T.; CARROL, J.:

Epigenetic modification during oocyte growth correlates with extended parthenogenetic development in the mouse. Nature Genet. 13 (1996), 91-94

KURE-BAYASHI, S.; MIYAKE, M.; OKADA, K.; KATO, S.:

Successful implantation of in vitro-matured, electro-activated oocytes in the pig. Theriogenology, 53 (2000), 1105-1119

NIEMANN, H.; RATH, D.:

Progress in reproductive biotechnology in swine. Theriogenology, 56 (2001), 1291-1204

O’NEILL, C. O.:

Evidence for the requirement of autocrine growth factors for development of mouse preimplantation embryos in vitro. Biol. Reprod., 56 (1997), 229-237

OZIL, J. P.:

The parthenogenetic development of rabbit oocytes after repetitive pulsatile electrical stimulation. Development, 109 (1990), 117-127

PERREAULT, S. D.; BARBEE, R. R.; SLOTT, V. I.:

Importance of glutathione in the acquisition and maintenance of sperm nuclear decondensing activity in maturing hamster oocytes. Dev. Biol., 125 (1988), 181-186

PRATHER, R. S.; MAYES, M. A.; MURPHY, C. N.:

Parthenogenetic activation of pig eggs by exposure to protein kinase inhibitors. Reprod. Fertil. Develop., 9 (1997), 441-446

SIROTKIN, A. V.; DUKESOVA, J.; MAKAREVICH, A.V.; KUBEK, A.; BULLA, J.: Evidence that growth factors IGF-I, IGF-II and EGF can stimulate nuclear maturation of porcine oocytes via intracellular protein kinase A. Reprod. Nutr. Dev., 40 (2000), 559-69

WILMUT, I.; YOUNG, L.; DeSOUSA, P.; KING, T.: New Opportunities in animal breeding and production- an introductory remark. Anim. Reprod. Sci., 6061 (2000), 5-14

YAMAUCHI, N.; NAGAI, T.:

Male Pronuclear formation in denudes porcine oocytes after in vitro maturation in the presence of cysteamine. Biol. Reprod., 61 (1999), 828-833

YOSHIDA, M.; ISHIGAKI, K.; PURSEL, V. G.:

Effect of maturation media on male pronucleus formation on pig oocytes matured in vitro. Mol. Reprod. Develop., 31 (1992), 68-71

YOSHIDA, M.; ISHIGAKI, K.; NAGAI, T.; CHIKYU, M.; PURSEL, V. G.:

Glutathione concentration during maturation and after fertilization in pig oocytes: relevance to the ability of oocytes to form a male pronucleus. Biol. Reprod., 49 (1993), 89-94 
Received: 2002-04-26

Accepted: 2002-09-24

Corresponding author

Dr. TATSUYUKI SUZUKI, PhD

Laboratory of animal Reproduction and Applied Biotechnology

The United Graduate School of Veterinary Sciences

Yamaguchi University

1677-1 Yoshida

753-8515 Yamaguchi City, Japan

E-Mail: suzuki@agr.yamaguchi-u.ac.jp 